\title{
Organizational Readiness and its Role in Developing the Managerial Skills of Managers in the National and Iraqi Insurance Companies
}

\section{Preparación organizacional y su papel en el desarrollo de las habilidades gerenciales de los gerentes en las compañías de seguros nacionales e iraquíes}

\author{
Maha Sabah Ibrahim \\ Higher Institute of Accounting and Financial Studies, University of Baghdad, Iraq \\ ORCID: https://orcid.org/0000-0002-3752-4145 \\ Nour Ali Salman \\ Higher Institute of Accounting and Financial Studies, University of Baghdad, Iraq \\ ORCID: https://orcid.org/0000-0001-5779-0128
}

Received 01-12-20 Revised 02-25-20 Accepted 06-20-20 On line 07-30-20

*Correspondence

Email: maha.sb@piafs.uobaghdad.edu.iq
Cite as:

Ibrahim, M.S, Salman, N.A. (2020). Organizational Readiness and Its Role in Developing the Managerial Skills of Managers in The National And Iraqi Insurance Companies. Propósitos y Representaciones, 8 (SPE2), e631. Doi: http://dx.doi.org/10.20511/pyr2020.v8nSPE2.631 


\section{Summary}

The objective of the research was to determine the role of organizational readiness in the development of management skills from the point of view of a sample of managers in the insurance companies of Aloni and Iraqi and the number of 37 directors, and was based on the questionnaire as a main tool in the collection of data and information, and was analyzed based on the statistical program (SPSS) In extract search results. The research reached the main conclusions: 1) There is a positive and positive relationship between organizational readiness and managerial skills. 2) There is a significant effect between organizational readiness and managerial skills.

Keywords: Organizational Readiness; Behaviorism; Management Skills.

\section{Resumen}

El objetivo de la investigación fue determinar el papel de la preparación organizacional en el desarrollo de habilidades de gestión desde el punto de vista de una muestra de gerentes en las compañías de seguros de Aloni e Iraq y el número de 37 directores, y se basó en el cuestionario como herramienta principal en la recopilación de datos e información, y se analizó en función del programa estadístico (SPSS) en los resultados de búsqueda de extracto. La investigación llegó a las principales conclusiones: 1) Existe una relación positiva y positiva entre la preparación organizacional y las habilidades gerenciales. 2) Hay un efecto significativo entre la preparación organizacional y las habilidades gerenciales.

Palabras clave: Preparación organizacional; Conductismo; Habilidades de gestión

\section{Introduction}

Change is inevitable. Things cannot stay the same. The environment imposes on the organization changes that may be ideological, economic, social, cultural, social, political or technical, or change from the working people themselves or from officials, Here, the organizations must adapt to ensure survival and continuity, and here the Organization's readiness and readiness to bring about constant coordination between the Organization's status and developments in the various areas of work. The process of developing the skills of managers is a process of continuous, renewable and comprehensive mobility in order to work to find qualified personnel to translate the objectives of the Department into action. This requires the creation of an effective system of functional barriers, which is based on creating balance in the principle of reward and punishment (Morsley, 2011, p. 19). Accordingly, the research will discuss the following:

The first topic: Research methodology.

The second topic: The theoretical framework of the research variables.

Third topic: View and discuss the research results.

The fourth topic: conclusions and recommendations.

\section{Method}

\section{Research problem}

Considering that the insurance industry is a global industry, indivisible from the international economic life and which contributes to the financing of the economic and social development plans of the countries, the insurance situation in Iraq must be examined in order to keep up with the progress of its economic activities and activities and to establish the correct and appropriate bases for interaction with developments and changes in the technical, And all areas of work. By answering the following questions: 
- How satisfied is the sample of organizational readiness and management skills?

- B. What is the relationship between organizational readiness and management skills development?

- C. Is there an impact of organizational readiness in the development of management skills?

\section{Research Objective}

- Determine the level of respondents' response to their organizational readiness in developing the management skills of the two companies.

- Identify the correlation between organizational readiness and the development of managerial skills.

- The extent of the influence of organizational readiness in developing the management skills of the research sample.

\section{The importance of research}

- Benefit from building theoretical foundations and bridging the cognitive gap of concepts (organizational readiness and development of managerial skills).

- Promote the reality of the insurance sector and develop scenarios to create a successful working environment that will help bring savings into high-yielding investments that contribute to economic development.

\section{The outline of the research hypothesis}

The research plan was based on the views of a number of researchers in determining the nature of correlation between the two variables, as shown in the following figure 1:

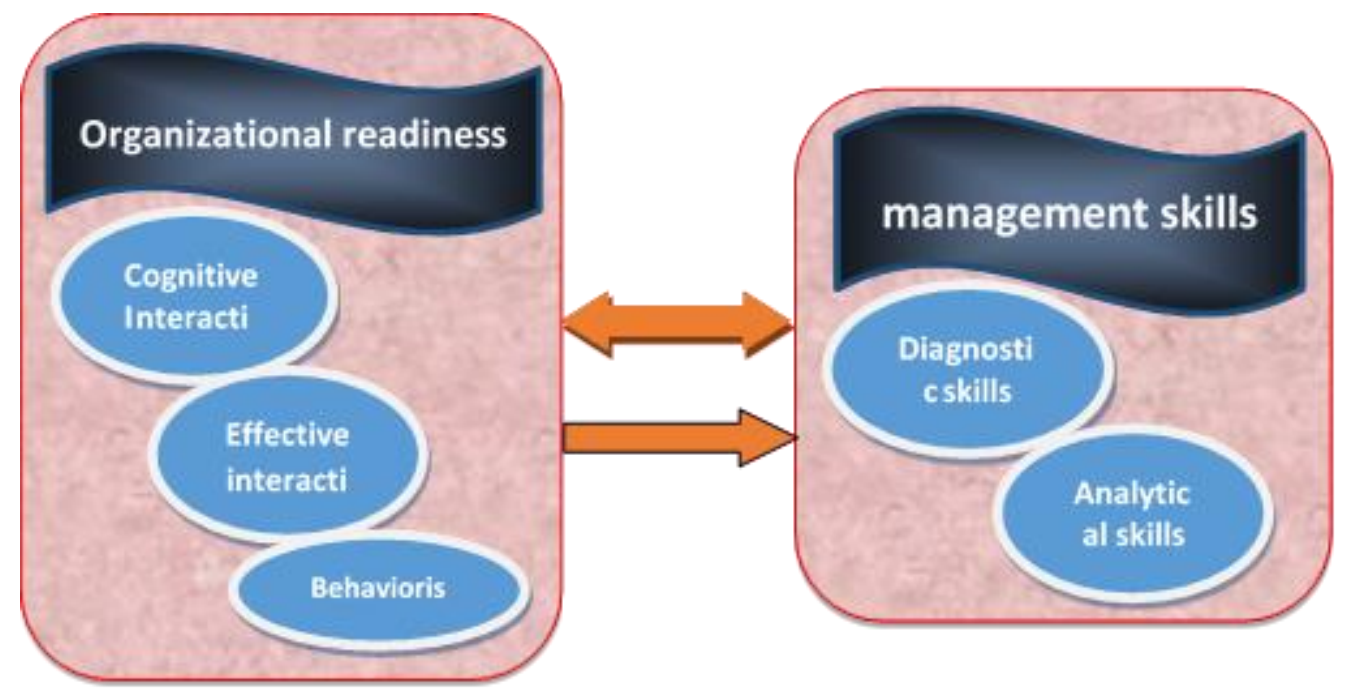

Figure 1. Outline of the search

The research relied on the descriptive approach to describe the reality of the investigated variables, as well as the analytical approach to analyze the results of the statistical treatments of the research variables and to draw the conclusions on which the recommendations are based.

Seventh: Research limits:

1. Time Limits: The research was completed during the year 2019.

2. Spatial boundaries: National and Iraqi insurance companies. 


\section{Research Sample and Description}

The random sample was chosen from the research community in the Iraqi National Insurance Company, represented by the category of managers in the two companies, because they are closest to the sample of the research, as well as for accurate results and reliability. (40) questionnaire forms were distributed to the sample. In contrast, the number of forms received was (37) questionnaire forms. Table 1, shows the description of the research sample as follows:

Table 1.

Characteristics of Sample Members

\begin{tabular}{|c|c|c|c|c|}
\hline No. & Variables & Categories & Repetition & ratio $\%$ \\
\hline \multirow[t]{3}{*}{1} & \multirow[t]{3}{*}{ Gender } & Males & 10 & 27.0 \\
\hline & & Female & 27 & 73.0 \\
\hline & & Total & 37 & 100.0 \\
\hline \multirow[t]{5}{*}{2} & \multirow[t]{5}{*}{ Age } & 30 years and less & 2 & 5.4 \\
\hline & & $31-40$ years & 9 & 24.3 \\
\hline & & $41-50$ years & 12 & 32.4 \\
\hline & & 51. More & 14 & 37.8 \\
\hline & & Total & 37 & 100.0 \\
\hline \multirow[t]{6}{*}{3} & \multirow[t]{6}{*}{ Qualification } & Secondary & 3 & 8.1 \\
\hline & & Technical Diploma & 2 & 5.4 \\
\hline & & Bachelor & 29 & 78.4 \\
\hline & & Higher Diploma & 1 & 2.7 \\
\hline & & Master's & 2 & 5.4 \\
\hline & & Total & 37 & 100.0 \\
\hline \multirow[t]{4}{*}{4} & \multirow{4}{*}{$\begin{array}{l}\text { Length of } \\
\text { service }\end{array}$} & $6-10$ years & 7 & 18.9 \\
\hline & & $11-15$ years & 4 & 10.8 \\
\hline & & More than 16 years & 26 & 70.3 \\
\hline & & Total & 37 & 100.0 \\
\hline \multirow[t]{5}{*}{5} & \multirow[t]{5}{*}{ Job Location } & Director general & 1 & 2.7 \\
\hline & & Director of the Department & 17 & 45.9 \\
\hline & & SUD Division & 12 & 32.4 \\
\hline & & Responsible unit & 7 & 18.9 \\
\hline & & Total & 37 & 100.0 \\
\hline
\end{tabular}

1. Gender: The percentage of males $(27.0 \%)$ of the total sample of the research, while $(73.0 \%)$ was for females. 
2. Age: The age group (more than 51 years) achieved the highest rate of (37.8\%), while the lowest rate (5.4\%) for the age group (less than 30 years), which explains the ownership of the two companies are diverse, , Or a certain age group, which gives the power to research in terms of taking the views of most of the age groups in the two companies.

3. The educational attainment: The majority of the sample members obtained the bachelor's degree, as they reached (29) of the total sample of the research and by (78.4\%), the highest percentage, and the number of holders of the Diploma of Technical and Master (2) (5.4\%). This indicates that the majority of respondents have a good culture and have sufficient scientific capacity to answer question questions, making the answers more precise and objective.

4. The period of service: The lowest percentage (10.8\%) of the sample, whose duration ranged between (11-15 years), and the highest rate (70.\%) ranged their service (more than 16 years), which shows that the sample in question is characterized Intellectual maturity, and skillful integration between all levels, and this creates a strength of study, especially in the answer of the sample on the paragraphs of the questionnaire, in terms of understanding and comprehension.

5. Job Location: The highest percentage of the respondents was $(45.9 \%)$ of the sample, while the lowest percentage (2.7\%) is the rank of General Manager.

The questionnaire is the basic tool on which the research was based. It consists of two main parts. The first was general information about the characteristics of the research sample. The second consists of (36) sections divided into two axes. The first axis consists of 22 paragraphs related to measurement of organizational readiness and its dimensions. (14) a measure for the development of management skills, which is on the scale of the five-fold Likert (strongly agree, agree, neutral, disagree, strongly disagree) and Bozan $(5,4,3,2,1)$, respectively.

The researcher adopted data analysis and processing on a number of statistical programs, including the package of the statistical program ready (Spss - Ver - 19).

Readiness begins as a concept of readiness to face a certain situation that deserves prior deliberation. It is said in the language: "I am prepared to prepare for it." A ready-made organization is an organization that is ready to face a certain order that is expected to occur. Management readiness means management's ability to prepare for a problem or something to be expected. Prevalence is not effective in management unless it is before the event and not after it, as it becomes a repair and treatment.

The readiness is a "strategic umbrella representing general guidelines for dealing with interlocking and unpredictable environments", or "the ability to respond quickly and with appropriate capacity when necessary, and to build capacity to manage all forms of emergency effectively" (Baby, 2011, pp. 45-46).

Attempts to implement new programs or policies are often unsuccessful in most organizations because administrative leaders do not have the organizational readiness to make change. The readiness is to understand the behavior of the working individuals, either to support or resist the process. They are those efforts by senior departments responsible for change.

Peach, Jimmieson and White (2005) define organizational readiness as (The positive perception individuals have about the need for change and the applications they practice themselves and with the organization as a whole) (Al-Hawajra, 2010, p.3). 
Organizational readiness refers to the extent to which members are prepared psychologically and behaviorally to implement organizational change. The higher the degree of readiness, the greater the tendency for members to change, and they make great efforts of perseverance and cooperation. This leads to more effective implementation. Conversely, whenever readiness is low, members will likely see that change is undesirable, Resistance to nonchange (Shea et al., 2014, p.2)

Al-Baghdadi (2008, p. 65) states that the organization's readiness for change is (the organization's ability to manage change). Here, the organization must possess seven characteristics to be ready for change:

1. Identifying and diagnosing the business environment and anticipating the various economic, technological and political changes.

2. The main role of leadership and stimulate the strategic initiatives of their organizations.

3. Building an organizational culture capable of expanding organizational capacity.

4. Management practices to make change.

5. The skill and ability of individuals to adapt and adapt to change situations.

6. Rewards received by working individuals that are of great benefit to them as a result of the change.

7. Organizational structure of the organization.

\section{Organizational Readiness Dimensions}

1. Cognitive Interaction: refers to the positive and negative thinking of individuals working to prepare for the development of their skills that help them to solve the problems experienced by the organization (Atwi, 2008, p. 9).

2. Affective interaction: The feelings and personal feelings of the working individuals that affect the readiness of the events of change in the organization, as the manager was more able to recognize those feelings and feelings will be able to deal with work groups that will be affected by change and enable it to expect reactions, behaviors and behaviors (Abdul Rahim, 2008, pp. 81-82).

3. Behaviorism: It is the human movement that cares about the human being and the attempt to liberate it from all that is old. It has given great importance to man and his mind in distinguishing and understanding and building normative judgments and rejecting everything that can limit man's creativity and effectiveness (Mehdi, 2002, pp.545-546).

\section{The concept of developing managerial skills}

Management skills are an important element in developing the performance of individuals working in business organizations, in developing themselves and in line with modern strategies in developing human resources to improve their performance and thus improve the performance of the organization. They are those processes aimed at increasing the abilities, skills and information of all individuals in society in general and in organizations in particular (Al-Hilu, 2010, p. 23).

Development takes a prominent place in the modern world. At a time when developed countries have gone beyond development, development is becoming more important in the developing world. Some believe that development is moving from one state to another through management by a conscious group that accommodates societal goals Which should be achieved. (:15th).

Management development is a continuous, sophisticated, renewable and comprehensive process that is based on understanding the environmental factors affecting the organization, 
designing the administrative structure capable of accommodating management activities, studying existing work methods and procedures, and modernizing the systems governing the work.

The skill is defined as the degree of accuracy in working as short as possible and at the lowest cost. It consists of speed, precision, comprehension. Skill is the ability that is developed and not necessarily innate, it appears in performance and not in possibilities, and the main criterion of skills is work. (Al-Qaisi and Mahmoud, 2015, p. 203).

(Griffin \& Moorhead, 2014, p. 12) that managers need a variety of skills including technical, personal, analytical and diagnostic skills. The importance of these skills varies according to organizational level. Analytical and diagnostic skills are the most important for senior managers in organizations. Technical skills the personality is more important to first line managers.

Here is the skill of the leadership in the management of subordinates to persuade them to actively contribute to their efforts in the performance of cooperative activity, and work continuously to influence individuals and convince them to accept work to achieve the goals of the Organization (Helou, 2010, p. 30).

There are three skills required to lead the subordinates within business organizations:

1. Human skills: any ability to interact and motivate.

2. Technical skills: any knowledge and efficiency.

3. Analytical skills: the ability to understand concepts, develop ideas and implement strategies. (Sharma, 2016, p. 166).

Sharma (2016, p. 166) argues that the task of each manager in an organization is to achieve organizational goals through appropriate use of human and material resources. As a human resource drives and uses material resources, the human resource is considered to be the most valuable asset in any organization. This requires that the manager be highly skilled and possess the art of selecting the human resource.

\section{The dimensions of management skills}

1. Diagnostic skills: Diagnostic Skills It is the ability of the manager to diagnose problems within the organization by studying the causes of them. The problem may be the increase in the turnover rate. When the situation is diagnosed, the reason for the deterioration of the interaction skills and the influence of the departmental supervisor, or diagnostic skills may take a positive direction. Then what is expected, and trying to look for reasons, for example, in the decline in prices of the company to a large degree, or increasing demand, which helps these skills to understand the situation. Griffin \& Moorhead, (2014, pp.11-12) states that managers use diagnostic skills to understand causal relationships and to find optimal solutions to problems.

With managers having analytic skills to analyze the problem and reach a reasonable solution, managers need to look for the root cause of the problem to be a real solution rather than just a solution. (Sharma, 2016, p. 167)

2. Analytical Skills: Analytical skills have become more important in today's chaotic business environment (Sharma, 2016, p. 167), which means the manager's ability to identify the underlying variables that led to the problem and to be studied and addressed, and to identify a number of possible alternatives, (Doyle, 2018, pp. 1-8). The important role of analytical skills refers to the ability to collect and analyze information, solve problems, and make decisions. 
Strengths help solve organizational problems and improve productivity and success. generally. What are the five analytical skills managers need to be present to their employees?

Individuals need strong analytical skills to reach optimal solutions to solve problems. These skills are (communication, creativity, critical thinking, data analysis, research).

- Communication: No matter what an individual has for strong analytical skills, he will not succeed if he cannot share the analysis with others, and by having effective communication with others that may be verbal or written, thus enhancing group productivity, interpersonal relationships and teamwork.

- Creativity: Requires working individuals to have the skill to think outside the box in order to arrive at effective solutions to the big problems.

- Critical Thinking: Any Process? For information and then make a decision based on the results reached.

- Data Analysis: No ability to scan large volumes of data and find trends in that data.

- Search: No problem finding and data collection.

Sharma (2016, p. 166-167) states that this skill is the ability to see the organization as a whole, ie the internal environment of the organization (strength and weakness), and the external environment (opportunities and threats). These skills allow the manager to solve problems strategically for business plans, and to harness resources to achieve organizational goals. The manager, who has a vision that looks at the problem from multiple angles, deals with it in many ways and develops a variety of solutions.

\section{Discuss the Research Results}

\section{Describe the responses of the sample to organizational readiness}

The results of Table 3 showed that the value of the total arithmetic mean of organizational readiness was (3.87), which is higher than the satisfactory mean of (3). This indicates that the majority of respondents agree that organizational readiness positively affects the development of management skills in Iraqi insurance companies (0.82), which indicates the homogeneity of the responses of the sample investigated for this variable, and the value of the total difference coefficient (13.87) and relative importance (77.96\%). The following is an explanation of the dimensions of organizational readiness:

\section{Cognitive Interaction}

This dimension has a general mathematical mean of 3.35. This indicates the agreement of the sample members to a medium extent on the importance of the paragraphs of this dimension, with a standard deviation of 0.97 and a coefficient of difference of 22.42 and a relative importance of $70.71 \%$ Paragraph (1) indicates that (the management of the company is looking forward to the change in the work) with a mean value of (4.19) and a standard deviation and coefficient of difference (0.78) and (16.29) respectively, with relative importance (81.24). This result indicates that this paragraph A high level of importance in the sample.

\section{Effective interaction}

This dimension has a general mean of 4.11, a standard deviation of 0.96 , a coefficient of difference of 8.40 and a relative importance of $82.26 \%$. Paragraph 13, which states: "The management of the company affects the behavior and behavior of the personnel working through training., Labor relations and work groups) at the highest mean (18.4), standard deviation (77.0), difference coefficient (94.15) and relative importance (84.83\%), while paragraph (12), which states (the management tends to do anything that supports readiness) At the lowest of the mean (65.3) and the standard deviation (10.1) and coefficient difference (22.30) and relative importance (04.73\%). 


\section{Behavioralism}

This dimension achieved a general mathematical mean of (3.70), a standard deviation (0.83), a difference coefficient of (22.40) and a relative importance (74.06\%). Paragraph (19) (75.78\%), while paragraph (21), which states that (the company's management seeks to develop the skills and knowledge in the company all) on the top of the account (94.3) and the standard deviation (02.1) and the difference coefficient (95.25) (52.3), standard deviation (82.0), difference coefficient (40.22) and relative importance $(06.74 \%$ ) (see Table 2 )

Table 2.

Arithmetic mean, standard deviation, coefficient of variation and relative importance of variables at sub-level and total organizational readiness

\begin{tabular}{|c|c|c|c|c|c|}
\hline No. & Paragraphs & $\begin{array}{l}\text { Arithmetic } \\
\text { mean }\end{array}$ & $\begin{array}{l}\text { standard } \\
\text { deviation }\end{array}$ & $\begin{array}{l}\text { Coefficient } \\
\text { of variation }\end{array}$ & $\begin{array}{l}\text { Relative } \\
\text { importance }\end{array}$ \\
\hline 1 & $\begin{array}{l}\text { The company's management looks } \\
\text { forward to making a change in the } \\
\text { business. }\end{array}$ & 4.19 & 0.78 & 16.29 & 81.24 \\
\hline 2 & $\begin{array}{l}\text { Management expects the results to be } \\
\text { useful as a result of readiness }\end{array}$ & 3.87 & 0.95 & 18.44 & 79.36 \\
\hline 3 & Management tends to try new ideas. & 3.54 & 1.02 & 26.40 & 70.99 \\
\hline 4 & $\begin{array}{l}\text { The management of the company is } \\
\text { concerned with the values and objectives } \\
\text { of the working individuals }\end{array}$ & 3.56 & 1.00 & 23.05 & 70.77 \\
\hline 5 & $\begin{array}{l}\text { The company's management provides } \\
\text { assistance to working personnel when } \\
\text { facing problems }\end{array}$ & 3.52 & 1.07 & 28.86 & 70.33 \\
\hline 6 & $\begin{array}{l}\text { The management of the company helps } \\
\text { all working personnel if they need any } \\
\text { service }\end{array}$ & 3.64 & 0.90 & 22.73 & 73.89 \\
\hline 7 & $\begin{array}{l}\text { The management of the company } \\
\text { exempts from unintentional errors issued } \\
\text { by the working personnel. }\end{array}$ & 3.44 & 1.00 & 29.14 & 68.79 \\
\hline 8 & $\begin{array}{l}\text { The company's management is ready to } \\
\text { make the proposed changes in order to } \\
\text { achieve the best. }\end{array}$ & 3.63 & 0.90 & 21.89 & 72.53 \\
\hline \multirow[t]{2}{*}{9} & $\begin{array}{l}\text { The Company's management believes } \\
\text { that most of the changes adversely affect } \\
\text { the Company's customers. }\end{array}$ & 3.41 & 1.22 & 30.17 & 69.55 \\
\hline & Cognitive Interaction & 3.55 & 0.97 & 22.42 & 70.71 \\
\hline 10 & $\begin{array}{l}\text { The readiness of the company's } \\
\text { management leads to the stimulation of } \\
\text { all working personnel. }\end{array}$ & 3.72 & 1.05 & 28.29 & 74.35 \\
\hline 11 & $\begin{array}{l}\text { The management of the company hears } \\
\text { proposals and new ideas by the working } \\
\text { individuals. }\end{array}$ & 4.17 & 890 & 11.29 & 83.36 \\
\hline 12 & $\begin{array}{l}\text { The company's management tends to do } \\
\text { anything that supports readiness. }\end{array}$ & 3.65 & 1.10 & 30.22 & 73.04 \\
\hline 13 & $\begin{array}{l}\text { The management of the company affects } \\
\text { the behavior and behavior of the } \\
\text { personnel employed through training, } \\
\text { relationships and work groups. }\end{array}$ & 4.18 & .770 & 15.94 & 83.84 \\
\hline
\end{tabular}




\begin{tabular}{|c|c|c|c|c|c|}
\hline 14 & $\begin{array}{l}\text { The management of the company seeks to } \\
\text { convince individuals working in logic to } \\
\text { be ready for any change. }\end{array}$ & 4.16 & 0.91 & 18.16 & 83.20 \\
\hline \multirow[t]{2}{*}{15} & $\begin{array}{l}\text { The company's management overcomes } \\
\text { the resistance of individuals working for } \\
\text { readiness by communicating and } \\
\text { providing useful information. }\end{array}$ & 4.12 & 0.97 & 23.55 & 82.39 \\
\hline & Effective interaction & 4.11 & .960 & 8.40 & 82.26 \\
\hline 16 & $\begin{array}{l}\text { Readiness helps improve unsatisfactory } \\
\text { situations in the company's business. }\end{array}$ & 3.81 & 1.04 & 27.20 & 76.25 \\
\hline 17 & $\begin{array}{l}\text { This change is commensurate with the } \\
\text { skills possessed by individuals working in } \\
\text { the company. }\end{array}$ & 3.69 & 0.89 & 24.10 & 73.75 \\
\hline 18 & $\begin{array}{l}\text { The management of the company } \\
\text { encourages the employees to make their } \\
\text { observations and suggestions about the } \\
\text { objectives. }\end{array}$ & 3.61 & 1.03 & 28.62 & 72.19 \\
\hline 19 & $\begin{array}{l}\text { The company's management works to } \\
\text { exchange information among individuals } \\
\text { to create new knowledge and skills that } \\
\text { are communicated to all. }\end{array}$ & 3.94 & 1.02 & 25.95 & 78.75 \\
\hline 20 & $\begin{array}{l}\text { The company's management is making } \\
\text { efforts to create flexibility for } \\
\text { modernization and seize opportunities. }\end{array}$ & 3.91 & 0.92 & 23.58 & 78.13 \\
\hline 21 & $\begin{array}{l}\text { The company's management seeks to } \\
\text { develop the skills and knowledge of the } \\
\text { company. }\end{array}$ & 3.52 & 0.98 & 27.76 & 70.31 \\
\hline \multirow[t]{3}{*}{22} & $\begin{array}{l}\text { The company's management discusses } \\
\text { individual mistakes and failure situations } \\
\text { to identify their causes and avoid them in } \\
\text { the future. }\end{array}$ & 3.73 & 0.82 & 21.99 & 74.69 \\
\hline & Behaviorism & 3.70 & $\mathbf{0 . 8 3}$ & 22.40 & 74.06 \\
\hline & Organizational readiness & 3.87 & 0.82 & 13.87 & 77.96 \\
\hline
\end{tabular}

\section{Description of the sample responses to the development of management skills}

The results of Table 3 showed that the mean of the total arithmetic mean of this variable was 3.76 , which is higher than the mean mean of (3), which means that the responses were medium and according to the sample of the sample. The standard deviation was 0.77 and the difference coefficient was 16.75) And relative importance (73.24\%). Here is an explanation for the dimensions of this variable:

\section{Diagnostic skills:}

(3.73), a standard deviation (0.83), a difference coefficient (22.46) and a relative importance $(73.91 \%)$. This indicates that the level of response to the paragraphs of this variable was medium. (4), which indicates that (the management of the company in carrying out the difficult tasks depends on individuals who have the ability to do so quickly) at the top of the mean of 94.3 and with a standard deviation of 0.92 and a difference coefficient of 46.23 and a relative importance of $75.78 \%$ ), While paragraph (6), which states (the management of the company has the freedom to put ideas and ideas by everyone to reach the solution) at the lowest and (47.3), standard deviation (04.1), difference coefficient (94.29) and relative importance (38.69\%). 


\section{Analytical skills:}

(3.84), with a standard deviation of (0.84) and a coefficient of difference (21.85) and a relative importance $(76.88 \%)$. The calculation ranged from 4.16 to 3.88 and paragraph (8) (0.78), a difference coefficient of (79.18) and a relative importance (13.83\%), while paragraph (14), which states (the management of the company is working on The correct communication between all organizational levels) at the lowest mean of (88.3) with a standard deviation (70.0), a difference coefficient of (10.18) and a relative importance (50.77\%).

Table 3.

The mean, the standard deviation, the coefficient of variation, and the relative importance of changes at the sub-level and total of managerial skills

\begin{tabular}{|c|c|c|c|c|c|}
\hline No. & Paragraphs & $\begin{array}{l}\text { Arithmetic } \\
\text { mean }\end{array}$ & $\begin{array}{l}\text { standard } \\
\text { deviation }\end{array}$ & $\begin{array}{l}\text { Coefficient } \\
\text { of variation }\end{array}$ & $\begin{array}{l}\text { Relative } \\
\text { importance }\end{array}$ \\
\hline 1 & $\begin{array}{l}\text { The company's management works to } \\
\text { engage individuals in quantitative courses } \\
\text { in statistics, accounting and finance. }\end{array}$ & 3.72 & 0.97 & 26.01 & 74.38 \\
\hline 2 & $\begin{array}{l}\text { The company's management works to } \\
\text { improve relationships with all working } \\
\text { individuals }\end{array}$ & 3.67 & 1.07 & 29.14 & 73.44 \\
\hline 3 & $\begin{array}{l}\text { The company's management has } \\
\text { personnel who are able to know why the } \\
\text { problem is occurring }\end{array}$ & 3.69 & 1.08 & 29.34 & 73.75 \\
\hline 4 & $\begin{array}{l}\text { The company's management in carrying } \\
\text { out difficult tasks depends on individuals } \\
\text { who have the ability to do so quickly }\end{array}$ & 3.94 & 0.92 & 23.46 & 78.75 \\
\hline 5 & $\begin{array}{l}\text { The management of the company seeks to } \\
\text { understand and understand the causes of } \\
\text { problems more than attention to } \\
\text { secondary issues }\end{array}$ & 3.64 & 1.16 & 31.86 & 72.81 \\
\hline 6 & $\begin{array}{l}\text { The management of the company has the } \\
\text { freedom to put forward opinions and } \\
\text { ideas by everyone to reach a solution. }\end{array}$ & 3.47 & 1.04 & 29.94 & 69.38 \\
\hline \multirow[t]{2}{*}{7} & $\begin{array}{l}\text { The management of the company } \\
\text { announces creative ideas and innovation } \\
\text { for the benefit of all. }\end{array}$ & 3.81 & 0.99 & 25.97 & 76.25 \\
\hline & Diagnostic skills & 3.70 & 0.83 & 22.46 & 73.91 \\
\hline 8 & $\begin{array}{l}\text { The company's management seeks to } \\
\text { develop individuals working on } \\
\text { achievement and self development. }\end{array}$ & 4.16 & 0.78 & 18.79 & 83.13 \\
\hline 9 & $\begin{array}{l}\text { The management of the company wishes } \\
\text { to have strong contacts and relationships } \\
\text { with the subordinates. }\end{array}$ & 4.11 & 0.80 & 19.45 & 82.19 \\
\hline 10 & $\begin{array}{l}\text { The company's management reinforces } \\
\text { the confidence of the subordinates } \\
\text { themselves by praising those who are } \\
\text { competent in front of their colleagues. }\end{array}$ & 3.89 & 0.84 & 21.54 & 77.81 \\
\hline 11 & $\begin{array}{l}\text { The management of the company } \\
\text { encourages the spirit of cooperation and } \\
\text { teamwork. }\end{array}$ & 3.92 & 0.76 & 19.44 & 78.44 \\
\hline
\end{tabular}




\begin{tabular}{|c|c|c|c|c|c|}
\hline 12 & $\begin{array}{l}\text { The company's management works to } \\
\text { build and provide a pattern of human } \\
\text { relations in which understanding and } \\
\text { participation prevail. }\end{array}$ & 4.05 & 0.86 & 21.31 & 80.94 \\
\hline 13 & $\begin{array}{l}\text { The company's circuit gives time to } \\
\text { innovate new ideas to do the job. }\end{array}$ & 4.05 & 0.82 & 20.38 & 80.94 \\
\hline 14 & $\begin{array}{l}\text { The company's management is working } \\
\text { to make the right communication between } \\
\text { all organizational levels. }\end{array}$ & 3.88 & 0.70 & 18.10 & 77.50 \\
\hline & Analytical skills & 3.84 & 0.84 & 21.85 & 76.88 \\
\hline & management skills & 3.76 & 0.77 & 16.75 & 73.24 \\
\hline
\end{tabular}

\section{Testing the hypothesis of research}

Test the hypothesis of correlation: The nature of the relationship between the variables of the research was determined to determine the acceptance or rejection of the first main hypothesis that: There is a significant correlation between organizational readiness and the development of managerial skills. It is clear from Table 4 that there is a positive correlation relationship with positive (positive) significance between organizational readiness and managerial skill development. The correlation value was $(0.711 * *)$ at the level of significance $(0.01)(100 \%)$. The highest sub-value of correlation coefficients in this axis between the effective interaction and the development of managerial skills was $(0.736 * *)$ at the level of significance $(0.01)$. This indicates the existence of a relationship of significant significance and its function. Management skills, and here we are based on the acceptance of the first main hypothesis.

Table 4.

Relationship between organizational readiness and management skills

\begin{tabular}{|c|c|c|c|c|c|c|c|}
\hline \multirow{2}{*}{$\begin{array}{l}\text { Organizational } \\
\text { readiness } \\
\text { management } \\
\text { skills Y }\end{array}$} & \multirow[b]{2}{*}{$\mathrm{X}$} & \multirow{2}{*}{$\begin{array}{l}\text { Cognitive } \\
\text { Interaction }\end{array}$} & \multirow{2}{*}{$\begin{array}{l}\text { Effective } \\
\text { interaction }\end{array}$} & \multirow[t]{2}{*}{ Behaviorism } & \multirow{2}{*}{$\begin{array}{l}\text { Organizational } \\
\text { readiness }\end{array}$} & \multicolumn{2}{|c|}{ Moral relations } \\
\hline & & & & & & Number & $\begin{array}{l}\text { The } \\
\text { ratio }\end{array}$ \\
\hline \multirow[t]{2}{*}{$\begin{array}{l}\text { management } \\
\text { skills }\end{array}$} & $\begin{array}{l}\text { Coefficient } \\
\text { of } \\
\text { correlation }\end{array}$ & $.705^{* *}$ & $.736^{* *}$ & $.723^{* *}$ & $.711^{* * *}$ & 4 & $100 \%$ \\
\hline & $\begin{array}{l}\text { the } \\
\text { decision }\end{array}$ & function & Function & Function & function & & \\
\hline
\end{tabular}

$(* *)$ The strength of the correlation and moral relationship (1\%).

(*)The strength of the correlation and moral relationship (5\%).

\section{Testing of influence hypotheses:}

Table 5, shows that the calculated value of $(\mathrm{F})$ was 51.83 , which is greater than the value of $(7.90)$ in the scale of (7.90) at the level of significance (1\%) and (0.000) (1.35). This results in a statistically significant effect of the independent variable (organizational readiness) in the dependent variable (managerial skills development) in the research sample. The value of the coefficient of determination (R2) was 0.663 , which accounted for $66.3 \%$ of the difference in (managerial skills development) and $33.7 \%$ was the explained variance of factors that did not enter the regression model. Therefore, these results provide sufficient support to accept the hypothesis of the second main research effect, which states (there is a significant effect of organizational readiness in the development of managerial skills). Table 4 shows that the value of the constant limit $(\mathrm{a}=0.562)$ is statistically significant. The calculated value of $\mathrm{t}(6.542)$ is greater than the t-table at the moral level $(1 \%)$ and the degree of freedom (35) $(\mathrm{B}=1.165)$ is 
statistically significant because the calculated value of $t$ (7.421) is greater than the $t$ tabular at the level of $1 \%$ and the degree of freedom (35) of 2.34. These results confirm that there is a strong effect of organizational readiness in development Management skills in the national and Iraqi insurance companies.

Table 6.

Effect of organizational readiness in management skills

The dependent management skills

variable

Independent

variable

\begin{tabular}{lllllllll}
\hline $\begin{array}{l}\text { Organizational } \\
\text { readiness }\end{array}$ & $\begin{array}{l}\text { Fixed } \\
\text { limit } \\
\mathrm{a}\end{array}$ & $\begin{array}{l}\text { Calculated } \\
\mathrm{t} \text { value }\end{array}$ & $\begin{array}{l}\text { Calculated } \\
\text { F value }\end{array}$ & $\begin{array}{l}\mathrm{R} 2 \\
\text { Selection } \\
\text { Factor }\end{array}$ & $\begin{array}{l}\text { Calculated } \\
\mathrm{t} \text { value }\end{array}$ & $\begin{array}{l}\text { Marginal } \\
\text { inclination } \\
\mathrm{b}\end{array}$ & Morality & $\begin{array}{l}\text { the } \\
\text { decision }\end{array}$ \\
& 0.562 & 6.542 & 1.165 & 7.421 & 0.663 & 51.83 & 0.000 & $\begin{array}{l}\text { There is } \\
\text { an } \\
\text { effect }\end{array}$
\end{tabular}

$*(\mathrm{f})$ The table is significant $5 \%$ and the degrees of freedom $(1.35)=(3.92)$

$* *(\mathrm{f})$ The table is significant $1 \%$ and the degrees of freedom $(1.35)=(7.90)$

$*(\mathrm{t})$ The table is significant $5 \%$ and the degrees of freedom $(35)=(1.67)$

$* *(\mathrm{t})$ The table is significant $1 \%$ and the degrees of freedom $(35)=(2.34)$

\section{Analysis of the Multiple Impact Hypothesis}

Table 6 , shows that the calculated $\mathrm{F}$ value is 21.67 , which is greater than the value of $(\mathrm{F})$ of the scale of (3.56) at the level of (0.01) and the (0.000) 4.32), which means that the independent variable (organizational readiness) has a significant effect on the dependent variable (management skills development) in the research sample. This means that the desired relationship is explained by the value of (R2) which reached (0.720) indicating that the dimensions of (organizational readiness) accounted for $(72.0 \%)$ in the dependent variable (management skills development) and $(28 \%)$ due to other factors. The value of the constant limit $(a=0.731)$ is statistically significant. The calculated value of $\mathrm{t}(4.178)$ is greater than the $\mathrm{t}$-table at the moral level $(1 \%)$ and the degree of freedom (32), Respectively $(b=0.525,0.745$ and 0.467$)$ were statistically significant because the calculated value of $t(5.173,6.172$ and 4.311) respectively was greater than the $t$-score of 2.34 at the mean level of 0.01 ) And to a degree of freedom. Which means that organizational readiness with their combined variables has a significant and strong impact in the development of managerial skills in the national and Iraqi insurance companies. 
Table 7.

Multivariate Effect (X) Organizational Readiness Variables in Management Skills

\begin{tabular}{llllllll}
\hline $\begin{array}{l}\text { Organizational } \\
\text { readiness }\end{array}$ & \multicolumn{2}{l}{ management skills } & & & & & \\
\cline { 2 - 5 } & $\begin{array}{l}\text { Regression } \\
\text { coefficients }\end{array}$ & $\begin{array}{l}\mathrm{t} \\
\text { Calculated }\end{array}$ & Morality & $\begin{array}{l}\mathrm{R} 2 \\
\text { Selection } \\
\text { Factor }\end{array}$ & $\begin{array}{l}\mathrm{F} \\
\text { Calculated }\end{array}$ & Morality & $\begin{array}{l}\text { the } \\
\text { decision }\end{array}$ \\
\hline Fixed limit & 0.731 & 4.178 & 0.000 & 0.720 & 21.67 & 0.000 & $\begin{array}{l}\text { There is } \\
\text { an } \\
\text { effect }\end{array}$ \\
$\begin{array}{l}\text { Cognitive } \\
\text { Interaction }\end{array}$ & 0.525 & 5.173 & 0.000 & & & & \\
\hline $\begin{array}{l}\text { Effective } \\
\text { interaction }\end{array}$ & 0.745 & 6.172 & 0.000 & & & & \\
\hline Behaviorism & 0.467 & 4.131 & 0.000 & & & & \\
\hline
\end{tabular}

*(f)The table is significant $5 \%$ and the degrees of freedom (4.32) $=(2.47)$

$* *(\mathrm{f})$ The table is significant $1 \%$ and the degrees of freedom (4.32) $=(3.56)$

$*(\mathrm{t})$ The table is significant $5 \%$ and the degrees of freedom (32) $=(1.67)$

$* *(\mathrm{t})$ The table is significant $1 \%$ and the degrees of freedom $(32)=(2.34)$

\section{Conclusions and Recommendations}

- There was a significant and positive correlation between organizational readiness and managerial skills.

- There is a significant and positive effect of organizational readiness in administrative skills.

- Multivariate effect of total organizational readiness variables in management skills.

- There is a lack of interest in dealing with unintended errors issued by working individuals.

- There is a weakness in the changes and formats in the company which in turn adversely affect the customers of the company.

\section{Recommendations}

- Working to deal with organizational readiness variables combined in management skills does not affect positively in the company.

- Treatment of unintended errors that are issued by the working personnel and exemption.

- Make changes and rotation of the work and individuals in the company in a professional and professional manner which in turn positively affect the customers of the company.

\section{References}

Abdel Rahim, S. S.A. (2008). Evaluating the Effectiveness of Change Management Strategies and Models for Some Sudanese Industrial and Service Establishments. PhD thesis in Business Administration, University of Khartoum.

Al-Atwi, A. A. H. (2008). The Effect of Structured Organizational Support on Personnel Preparedness for Change. Applied Study at Muthanna Cement Factory. https://WWW.researchgate.net/publication/30001357

Al-Baghdadi, A. H. (2008). The relationship between the characteristics of the educated organization and its readiness for change / a comparative study in two faculties of private higher education in Baghdad. Qadisiya Journal of Administrative Sciences and Economics, 1.

Al-Hawajza, K. M. (2011). The Organizational Preparedness for Strategic Change in the Organization. Jordan Journal of Business Administration, 7(3). 
Al-Qaisi and Mahmoud, Fadel Hamad and Zidkhoam, (2015). Leadership skills and their impact on strategic planning: applied research in the Ministry of Planning. Journal of Economic and Administrative Sciences, 21(86), 196-226.

Al-Salem and Al-Ajlouni, Moayad and Muhammad (2008). Organizations Prepared for Change: A Missing Episode in Change Management. 8th Scientific Conference: Change Management and Knowledge Society, Al-Zaytoonah University, Jordan.

Doyle, A. (2018). Analytical Skills Definition, List, and Examples.

Durrat, O. M. (2009). Introduction to Management. Aleppo, Dar al-Basel.

El-Helou, A. A. M. (2010). The Effect of Delegation of Powers on the Development of Administrative Skills of Employees: A Field Study on Palestinian Universities in the Gaza Strip. Master of Business Administration, Faculty of Commerce, Islamic University / Gaza.

Griffin, R.W., \& Moorhead, G., (2014). Organizational Behavior: Managing People and Organizations. 10th ed., South - Western.

Hawazza, K. M. (2010). The Organization of Learned and Organizational Preparedness for Strategic Change. Journal of Human Sciences, 45(7), 12-27.

Holt, D.T., Armenakis, A.A., Field, H.S., \& Harris, S.G. (2007). Readiness for Organizational Change: The Systematic Development of a scale. The Journal of Applied Behavioral Science, 43(2), 232 - 255.

Infant, K.W.J. (2011). Preparedness for Crisis and Disaster Management". Survey of Civil Defense Officers in the Gaza Strip, Master Thesis, Faculty of Commerce / Department of Business Administration, Gaza.

Mahdi, A. S. (2002). Humanism in Contemporary Western Political Thought. Political and International Journal, University of Baghdad.

Mursalli, R. B. (2011). Modern methods of administrative development between the inevitability of change and constraints of application / case study of Algeria: 2001-2011. Master of Political Science and International Relations, Mouloud Mameri University - Tizi Ouzou, Faculty of Law.

Mursley, R. B. (2011). Modern Methods of Administrative Development between the Imperative of Change and the Impediments of Application / Case Study of Algeria: 2001-2011. Master of Political Science and International Relations, Mouloud Mameri University Tizi Ouzou, Faculty of Law.

Sharma, M.L. (2016). Different Managerial Skills in Corporate Governance. Paripex - Indian Journal of Research, 5(9), 166-167.

Shea, C.M., Jacobs, S.R., Esserman, D.A., Bruce., \& Weiner, B. (2014). Organizational readiness for implementing Change: a Psychometric assessment of a new measure. http://WWW.implemetationscince.comlcontent/9/1/7.

Shubair, A. S. (2007). The Impact of Some Elements of Organizational Culture on Crisis Preparedness at Nasser Hospital. Master Thesis in Management / Faculty of Commerce, Gaza.

Weiner, B.J. (2009). A theory of Organizational readiness for change. Implementation Science. Whetten, D.A., \& Cameron, K.S. (2011). Developing Management Skills. 8th ed., Prentice Hall. 